\title{
VELOCITY PATTERNS AND ELEVATIONS ON ICE STREAM B
}

\author{
(Abstract) \\ by \\ M. Jackson and I.M. Whillans
}

(Byrd Polar Research Center, The Ohio State University, Columbus, OH 43210, U.S.A.)

All of the West Antarctic ice sheet draining into the Ross Ice Shelf lies on bedrock which is below sea level. This is thought to make it especially senstitive to rapid decay which could be triggered by an increase in atmospheric $\mathrm{CO}_{2}$ levels. ice stream $\mathrm{B}$, one of the main outlets of the West Antarctic Ice Sheet, is thinning, possibly in response to changes in climate. However, Ice Stream C, its neighbor, is thickening.

One of the most effective ways to study ice streams is by repeat aerial photogrammetry. Thousands of velocity values and elevations are available for Ice Stream B using this technique. Two sections of the ice stream have repeat photogrammetry with control. Maps of elevations, velocity components and velocity gradients have been produced following the methods of Brecher (1986).
The area considered here is a 40 by $30 \mathrm{~km}$ block across a part of the ice stream. The maps show that most of the increase in longitudinal velocity occurs within about $6 \mathrm{~km}$ of the ice-stream margin and reaches a maximum of $460 \mathrm{~m} \mathrm{a}^{-1}$ in the center of the stream. Strain rates in the shear margins reach $0.12 \mathrm{a}^{-1}$ and are an order of magnitude less in the main body of the stream.

The elevation maps show ridges and troughs. These features appear to be related to transverse velocities.

\section{REFERENCE}

Brecher, H.H. 1986. Surface velocity determination on large polar glaciers by aerial photogrammetry. Ann Glaciol., 8, $22-26$.

\section{ICE-OCEAN INTERACTION ON RONNE ICE SHELF, ANTARCTICA}

\section{(Abstract)}

\author{
by
}

\author{
A. Jenkins and C.S.M. Doake
}

(British Antarctic Survey, Natural Environment Research Council, High Cross, Madingley Road, Cambridge CB3 OET, U.K.)

\begin{abstract}
A detailed glaciological study of Ronne Ice Shelf has been undertaken along a flowline extending from Rutford Ice Stream grounding line to the ice front. Measurements of velocity, surface elevation, ice thickness, surface temperature and accumulation rate have been made at a total of 28 sites; at 17 of these ice deformation rates are also known. Although no direct measurements of basal conditions have been made, these can be deduced from observations made at the surface. Assuming the ice shelf to be in a steady state, the basal mass balance can be calculated at points where strain-rates are known. Information on the spatial distribution of basal saline ice layers can also be obtained from radio-echo sounding data. The derived pattern of basal melting and freezing influences both the ice shelf and the underlying ocean. Vertical heat advection modifies the temperature distribution within the ice shelf, which determines its dynamic response to driving and restraining forces through the temperature-dependent ice-flow law. Using measured strain-rates and calculated temperature profiles, the restraint generated by horizontal shear stresses
\end{abstract}

can be derived for points on the flowline. It is the cumulative effect of these forces which controls the discharge of grounded ice from Rutford Ice Stream. Cooling of sea-water to its pressure melting point by melting of ice at depth has two important results. The outflow of cold, dense Ice Shelf Water, produced by this mechanism, is a major source of Antarctic Bottom Water, formed as it mixes at depth with the warmer waters of the Weddell Sea (Foldvik and Gammelsrød, 1988). If the cold water is forced up to shallower depths, frazil ice will be produced as the pressure freezing point rises, resulting in basal accretion if this occurs beneath the ice shelf.

\section{REFERENCE}

Foldvik, A. and T. Gammelsrød. 1988. Notes on Southern Ocean hydrography, sea-ice and Bottom Water formation. Palaeogeog., Palaeoclimat., Palaeoecol., 67, 3-17. 